\title{
Three New Compounds from Kadsura longipedunculata
}

\author{
Jian-Xin Pu, ${ }^{a}$ Xue-Mei GaO,${ }^{a}$ Chun LeI,${ }^{a}$ Wei-Lie XIAO,${ }^{a}$ Rui-Rui WAnG,${ }^{b}$ Li-Bin YANG,${ }^{a}$ \\ Yong ZhaO, ${ }^{a}$ Li-Mei LI, ${ }^{a}$ Sheng-Xiong Huang, ${ }^{a}$ Yong-Tang Zheng, ${ }^{b}$ and Han-Dong Sun ${ }^{*}, a$ \\ ${ }^{a}$ State Key Laboratory of Phytochemistry and Plant Resources in West China, Kunming Institute of Botany, Chinese \\ Academy of Sciences; Kunming 650204, P. R. China: and ${ }^{b}$ Laboratory of Molecular Immunopharmacology, Key \\ Laboratory of Animal Models and Human Disease Mechanisms, Kunming Institute of Zoology, Chinese Academy of \\ Sciences; Kunming 650223, Yunnan, P. R. China.
}

Received March 20, 2008; accepted April 30, 2008; published online May 29, 2008

Two new tetrahydrofuran lignans, kadlongirins A and B (1, 2), a new cadinane-type sesquiterpenoid, 2,7-dihydroxy-11,12-dehydrocalamenene (3), together with seven known lignans, grandisin, fragransin $B_{1}$, vladirol $F$, kadsuralignan C, otobaphenol, isoanwulignan, and 4-[4-(3,4-dimethoxyphenyl)-2,3-dimethylbutyl]-2-methoxyphenol, were isolated from the leaves and stems of Kadsura longipedunculata. The structures of these new compounds were elucidated by spectroscopic methods. Compound 2 exhibited weak anti-human immunodeficiency virus-1 activity with an $\mathrm{EC}_{50}$ value of $16.0 \mu \mathrm{g} / \mathrm{ml}$, and therapeutic index (TI) value of 6.7.

Key words Kadsura longipedunculata; lignan; sesquiterpenoid; anti-human immunodeficiency virus activity

Kadsura longipedunculata FINET et GAGNEP is a climbing plant widely distributed in the southern part of China. It has been used in folk medicine for the treatment of rheumatoid arthritis as well as gastric and duodenal ulcers. ${ }^{1,2)}$ This species has been reported to contain dibenzocyclooctadienlignans, lanostane triterpenoid acids, and lactones, which have been found to possess some beneficial pharmacological effects, including antihepatitis, antitumor, and anti-human immunodeficiency virus (HIV) activities. ${ }^{3-10)}$ Recently, we reported the isolation and structure elucidation of two novel series of triterpene dilactones with unprecedented rearranged skeletons, named as kadlongilactones $\mathrm{A}-\mathrm{F}$ and longipedlactones $\mathrm{A}-\mathrm{I}$, respectively, from the leaves and stems of $K$. longipedunculata collected in the Erlang mountain region of Sichuang Province, China. ${ }^{1-13)}$ To search more novel and biologically potent active compounds, and to compare the chemical constituents' differences of the same Kadsura species belonging to different geographical distribution and climatic conditions, we investigated the leaves and stems of $K$. longipedunculata collected in the Yibin region of Sichuang Province, China. This paper deals with the isolation and structure elucidation of three new compounds, named as kadlongirins $\mathrm{A}$ and $\mathrm{B}(\mathbf{1}, \mathbf{2})$ and 2,7-dihydroxy11,12-dehydrocalamenene (3), together with seven known compounds, grandisin (4), ${ }^{14)}$ fragransin $\mathrm{B}_{1}(\mathbf{5}),{ }^{15)}$ vladirol $\mathrm{F}$ $(6),{ }^{16)}$ kadsuralignan $\mathrm{C}(7),{ }^{17)}$ otobaphenol (8), ${ }^{18)}$ isoanwulignan (9), ${ }^{19)}$ and 4-[4-(3,4-dimethoxyphenyl)-2,3-dimethylbutyl]-2-methoxy-phenol (10). ${ }^{20)}$ The anti-HIV-1 activities of the three new compounds were evaluated. Compound 2 showed weak anti-HIV-1 activity with an $\mathrm{EC}_{50}$ value of $16.0 \mu \mathrm{g} / \mathrm{ml}$ and therapeutic index (TI) value of 6.7 .

\section{Results and Discussion}

Compound 1 was obtained as yellowish oil and its molecular formula of $\mathrm{C}_{24} \mathrm{H}_{32} \mathrm{O}_{8}$ was established from HR-ESI-MS $\left([\mathrm{M}+\mathrm{Na}]^{+}, m / z\right.$ 471.1994) and ${ }^{13} \mathrm{C}-\mathrm{NMR}$ spectroscopic data, indicating 9 degrees of unsaturation. The IR spectrum showed the presence of a hydroxyl group $\left(3426 \mathrm{~cm}^{-1}\right)$ and aromatic moieties $\left(1593,1512,1463 \mathrm{~cm}^{-1}\right)$, and a very intense absorption band at $1126 \mathrm{~cm}^{-1}$ suggested $\mathrm{C}-\mathrm{O}-\mathrm{C}$ functionalities. Its ${ }^{1} \mathrm{H}-\mathrm{NMR}$ spectrum (Table 1) suggested $\mathbf{1}$ as an asymmetric tetrahydrofuran lignan, ${ }^{21,22)}$ since signals corresponding to an oxybenzyl methine $\left(\delta_{\mathrm{H}} 4.80, \mathrm{~d}, 10.1 \mathrm{~Hz}\right)$ and two methyl protons $\left(\delta_{\mathrm{H}} 1.31, \mathrm{~s} ; 0.94, \mathrm{~d}, 6.8 \mathrm{~Hz}\right)$ could be observed. The chemical shifts observed for aromatic protons at $\delta_{\mathrm{H}} 6.74(\mathrm{~s}, 2 \mathrm{H}), 6.97(\mathrm{~d}, 8.3 \mathrm{~Hz}, 1 \mathrm{H}), 7.08(\mathrm{~d}, 8.3 \mathrm{~Hz}, 1 \mathrm{H})$, and $7.12(\mathrm{~s}, 1 \mathrm{H})$, associated with the presence of intense singlets corresponding to five methoxyl protons $\left(\delta_{\mathrm{H}} 3.76,3 \mathrm{H}\right.$; $3.84,3 \mathrm{H} ; 3.85,3 \mathrm{H} ; 3.86,6 \mathrm{H})$, indicated the substitution pattern as 3,4-dimethoxyphenyl and $3^{\prime}, 4^{\prime}, 5^{\prime}$-trimethoxyphenyl for the two aromatic rings. The ${ }^{13} \mathrm{C}-\mathrm{NMR}$ spectrum (Table 1) corroborated the assignments made for the structural determination of both aromatic rings. As expected, the symmetric $3^{\prime}, 4^{\prime}, 5^{\prime}$-trimethoxyphenyl ring displayed only four different

Table 1. ${ }^{1} \mathrm{H}$ - and ${ }^{13} \mathrm{C}-\mathrm{NMR}$ Assignments of $\mathbf{1}$ and $\mathbf{2}$

\begin{tabular}{|c|c|c|c|c|}
\hline \multirow{2}{*}{ Position } & \multicolumn{2}{|r|}{1} & \multicolumn{2}{|r|}{2} \\
\hline & $\delta_{\mathrm{C}}$ (mult.) & $\delta_{\mathrm{H}}$ (mult., $J, \mathrm{~Hz}$ ) & $\delta_{\mathrm{C}}$ (mult.) & $\delta_{\mathrm{H}}($ mult., $J, \mathrm{~Hz})$ \\
\hline 1 & $130.8 \mathrm{~s}$ & & $130.4 \mathrm{~s}$ & \\
\hline 2 & $113.4 \mathrm{~d}$ & $7.12(\mathrm{~s})$ & $113.2 \mathrm{~d}$ & $7.06(\mathrm{~s})$ \\
\hline 3 & $149.9 \mathrm{~s}$ & & $150.8 \mathrm{~s}$ & \\
\hline 4 & $150.4 \mathrm{~s}$ & & $150.0 \mathrm{~s}$ & \\
\hline 5 & $112.2 \mathrm{~d}$ & $6.97(\mathrm{~d}, 8.3)$ & $112.3 \mathrm{~d}$ & $6.98(\mathrm{~d}, 8.4)$ \\
\hline 6 & $122.2 \mathrm{~d}$ & $7.08(\mathrm{~d}, 8.3)$ & $121.7 \mathrm{~d}$ & $7.07(\mathrm{dd}, 2.0,8.4)$ \\
\hline 7 & $113.7 \mathrm{~s}$ & & $109.4 \mathrm{~s}$ & \\
\hline 8 & $83.5 \mathrm{~s}$ & & $73.5 \mathrm{~s}$ & \\
\hline 9 & $19.4 \mathrm{q}$ & $1.31(\mathrm{~s})$ & $10.8 \mathrm{q}$ & $1.44(\mathrm{~s})$ \\
\hline $1^{\prime}$ & $138.6 \mathrm{~s}$ & & $136.2 \mathrm{~s}$ & \\
\hline $2^{\prime}$ & $105.7 \mathrm{~d}$ & $6.74(\mathrm{~s})$ & $106.9 \mathrm{~d}$ & $6.91(\mathrm{~s})$ \\
\hline $3^{\prime}$ & $154.5 \mathrm{~s}$ & & $154.7 \mathrm{~s}$ & \\
\hline $4^{\prime}$ & $139.2 \mathrm{~s}$ & & $140.2 \mathrm{~s}$ & \\
\hline $5^{\prime}$ & $154.5 \mathrm{~s}$ & & $154.7 \mathrm{~s}$ & \\
\hline $6^{\prime}$ & $105.7 \mathrm{~d}$ & $6.74(\mathrm{~s})$ & $106.9 \mathrm{~d}$ & $6.91(\mathrm{~s})$ \\
\hline $7^{\prime}$ & $89.0 \mathrm{~d}$ & $4.80(\mathrm{~d}, 10.1)$ & $87.7 \mathrm{~d}$ & $5.12(\mathrm{~s})$ \\
\hline $8^{\prime}$ & $50.4 \mathrm{~d}$ & $2.44(\mathrm{~m})$ & $71.3 \mathrm{~s}$ & \\
\hline $9^{\prime}$ & $8.9 \mathrm{q}$ & $0.94(\mathrm{~d}, 6.8)$ & $12.8 \mathrm{q}$ & $1.15(\mathrm{~s})$ \\
\hline 3-OMe & $56.4 \mathrm{q}$ & $3.84(\mathrm{~s})$ & $56.4 \mathrm{q}$ & $3.85(\mathrm{~s})$ \\
\hline 4-OMe & $56.4 \mathrm{q}$ & $3.85(\mathrm{~s})$ & $56.5 \mathrm{q}$ & $3.85(\mathrm{~s})$ \\
\hline 7-OMe & $50.6 \mathrm{q}$ & $3.21(\mathrm{~s})$ & $50.7 \mathrm{q}$ & $3.13(\mathrm{~s})$ \\
\hline 3'-OMe & $56.6 \mathrm{q}$ & $3.86(\mathrm{~s})$ & $56.5 \mathrm{q}$ & $3.87(\mathrm{~s})$ \\
\hline $4^{\prime}-\mathrm{OMe}$ & $61.1 \mathrm{q}$ & $3.76(\mathrm{~s})$ & $61.1 \mathrm{q}$ & $3.74(\mathrm{~s})$ \\
\hline $5^{\prime}-\mathrm{OMe}$ & $56.6 \mathrm{q}$ & $3.86(\mathrm{~s})$ & $56.5 \mathrm{q}$ & $3.87(\mathrm{~s})$ \\
\hline
\end{tabular}

All spectra were recorded in $\mathrm{CD}_{3} \mathrm{OD}$ at $400 \mathrm{MHz} . \delta$ in ppm, $J$ in $\mathrm{Hz}$. 

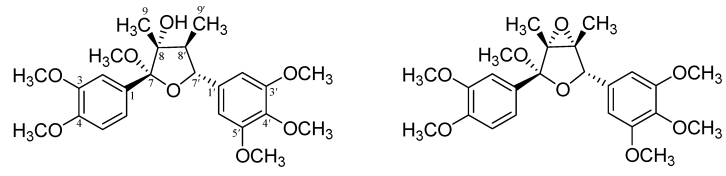<smiles>C=C(C)[C@H]1C[C@H](O)[C@H](C)c2cc(O)c(C)cc21</smiles>
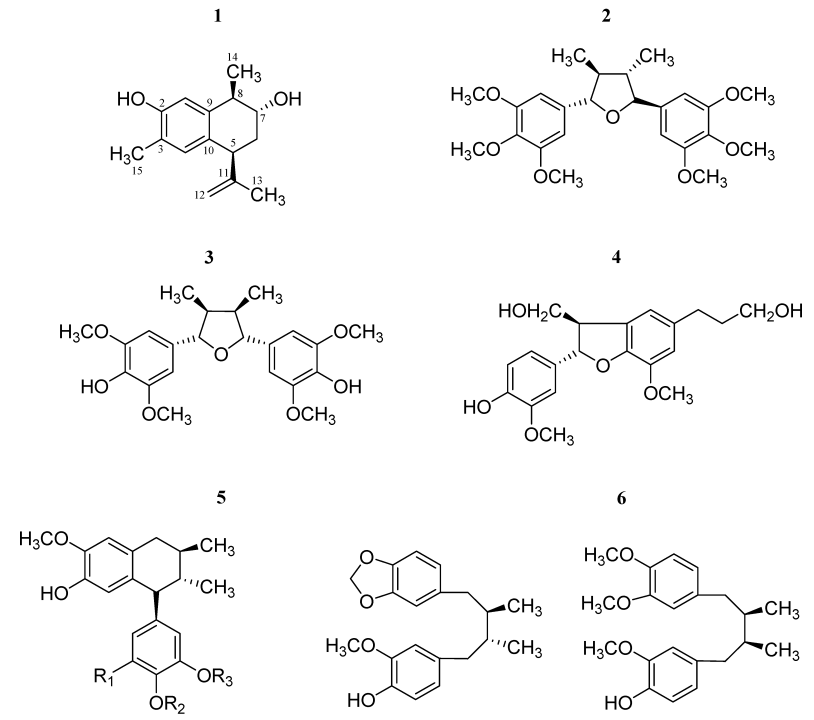

$7 \mathrm{R}_{1}=\mathrm{OMe}, \mathrm{R}_{2}=\mathrm{H}, \mathrm{R}_{3}=\mathrm{Me}$ $8 \mathrm{R}_{1}=\mathrm{H}, \mathrm{R}_{2}=\mathrm{R}_{2}=\mathrm{CH}_{2}$

10

Fig. 1. The Structures of Compounds $\mathbf{1}-\mathbf{1 0}$ (a)

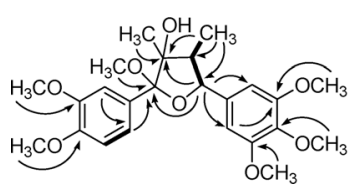

(b)

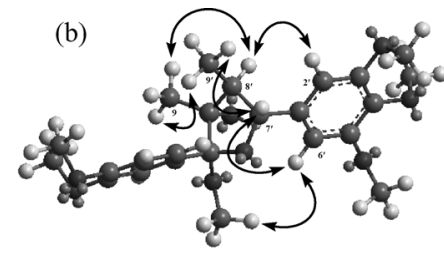

Fig. 2. (a) ${ }^{1} \mathrm{H},{ }^{1} \mathrm{H} \operatorname{COSY}(-)$ and $\operatorname{Key} \operatorname{HMBC}(\mathrm{H} \rightarrow \mathrm{C})$ Correlations of $\mathbf{1}$; (b) Key ROESY $(\leftrightarrow)$ Correlations of $\mathbf{1}$

chemical shifts for aromatic carbons $\left(\delta_{\mathrm{C}} 105.7,138.6,139.2\right.$, 154.5), while for the second aromatic ring bearing two methoxyl groups, the corresponding signals could be assigned $\left(\delta_{\mathrm{C}} 112.2,113.4,122.2,130.8,149.9,150.4\right)$. Extensive analysis of $\mathrm{HSQC},{ }^{1} \mathrm{H}-{ }^{1} \mathrm{H}$ COSY, and $\mathrm{HMBC}$ spectral data led to the establishment of the functional groups (Fig. 2). The HMBC correlations from $\mathrm{H}-7^{\prime}$ to $\mathrm{C}-2^{\prime}$ and $\mathrm{C}-6^{\prime}$, and from $\mathrm{H}-2, \mathrm{H}-6$ to $\mathrm{C}-7$, confirmed the location of each oxygenated aromatic ring to the tetrahydrofuran ring. The HMBC correlations from methoxyl protons to $\mathrm{C}-3, \mathrm{C}-4, \mathrm{C}-$ $3^{\prime}, \mathrm{C}-4^{\prime}$, and $\mathrm{C}-5^{\prime}$ indicated that the five methoxyl groups are attached at C-3, C-4, C-3', C-4', and C-5', respectively. Except for the presence of the above five methoxyl groups, an especially upfield signal of methoxyl group $\left(\delta_{\mathrm{H}} 3.21, \delta_{\mathrm{C}}\right.$ 50.6) was observed in ${ }^{1} \mathrm{H}$ - and ${ }^{13} \mathrm{C}$-NMR spectrum, which was attached at $\mathrm{C}-7$. This was established by HMBC correlation observed from methoxyl protons to $\mathrm{C}-7$ and the relative downfield shift of $\mathrm{C}-7\left(\delta_{\mathrm{C}} 113.7, \mathrm{~s}\right)$. In addition, the HMBC correlations from $\mathrm{H}_{3}-9, \mathrm{H}_{3}-9^{\prime}, \mathrm{H}-7^{\prime}$ to the oxygenated quaternary carbon $\mathrm{C}-8\left(\delta_{\mathrm{C}} 83.5, \mathrm{~s}\right)$, along with the analysis of its molecular formula, indicated that $\mathrm{C}-8$ of 1 was substituted by a hydroxyl group. The relative configuration of $\mathbf{1}$ was shown
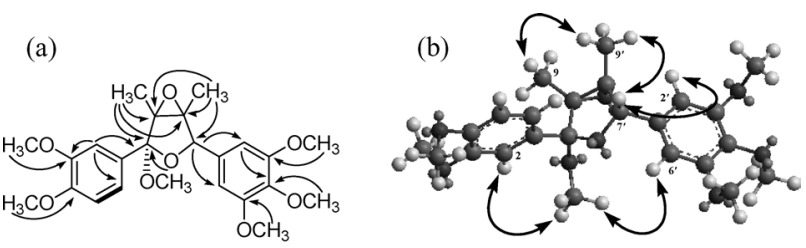

Fig. 3. (a) ${ }^{1} \mathrm{H},{ }^{1} \mathrm{H} \operatorname{COSY}(-)$ and Key HMBC $(\mathrm{H} \rightarrow \mathrm{C})$ Correlations of 2; (b) Key ROESY $(\leftrightarrow)$ Correlations of 2

to be as depicted in Fig. $2 \mathrm{~b}$ by the correlations observed in a ROESY experiment. ROESY correlations were observed between $\mathrm{H}-7^{\prime}$ and $\mathrm{H}-6^{\prime}\left(\mathrm{H}-2^{\prime}\right), \mathrm{H}_{3}-9$ and $\mathrm{H}_{3}-9^{\prime}$; $\mathrm{H}-7^{\prime}$ also gave a ROESY correlation to $\mathrm{H}_{3}-9^{\prime}$, which established that $\mathrm{H}-7^{\prime}$, $\mathrm{H}_{3}-9^{\prime}$, and $\mathrm{H}_{3}-9$ were in $\beta$-orientation, and the ROESY correlations of $\mathrm{H}-8^{\prime}$ with $\mathrm{H}-2^{\prime}\left(\mathrm{H}-6^{\prime}\right)$, and $\mathrm{CH}_{3} \mathrm{O}-7$ with $\mathrm{H}-6^{\prime}(\mathrm{H}-$ $\left.2^{\prime}\right)$ indicated $\mathrm{H}-8^{\prime}$ and $\mathrm{CH}_{3} \mathrm{O}-7$ were in $\alpha$-orientation. Thus the structure of $\mathbf{1}$ was determined, and named as kadlongirin A. Note that compound $\mathbf{1}$ is the first example of a tetrahydrofuran lignan substituted at C-7 with a methoxyl group in Kadsura species.

Compound 2, obtained as yellowish oil, had the molecular formula $\mathrm{C}_{24} \mathrm{H}_{30} \mathrm{O}_{8}$, as derived from HR-ESI-MS at $\mathrm{m} / \mathrm{z}$ $469.1850\left([\mathrm{M}+\mathrm{Na}]^{+}\right.$, Calcd 469.1838). The UV, IR, and NMR spectra established that 2 possessed tetrahydrofuran lignan skeleton, ${ }^{21,22)}$ differing from 1 by the loss of two hydrogens. Detailed comparison of ${ }^{1} \mathrm{H}$ - and ${ }^{13} \mathrm{C}-\mathrm{NMR}$ data of $\mathbf{2}$ with those of 1 showed close analogy. The major differences included the appearance of a tetrasubstituted epoxide $\left(\delta_{\mathrm{C}}\right.$ $71.3, \mathrm{~s} ; 73.5, \mathrm{~s})$ in $\mathbf{2}$ and disappearance of a methine $\left(\delta_{\mathrm{C}}\right.$ 50.4 , d) in 1. The HMBC (Fig. 3a) correlations from $\mathrm{H}_{3}-9$ and $\mathrm{H}_{3}-9^{\prime}$ to $\mathrm{C}-8$ and $\mathrm{C}-8^{\prime}$, respectively, further verified that the epoxide group was positioned between $\mathrm{C}-8$ and $\mathrm{C}-8^{\prime}$. In the ROESY (Fig. 3b) experiment, $\mathrm{H}_{3}-9^{\prime}$ showed strong correlations with $\mathrm{H}_{3}-9$ and $\mathrm{H}-7^{\prime}$, and $\mathrm{H}^{-} 7^{\prime}$ with $\mathrm{H}-2^{\prime}\left(\mathrm{H}-6^{\prime}\right.$ ), indicating an $\alpha$-orientation of the epoxide group. $\mathrm{CH}_{3} \mathrm{O}-7\left(\delta_{\mathrm{H}}\right.$ $3.13, \mathrm{~s})$ showed correlation with $\mathrm{H}-2$ and $\mathrm{H}-6^{\prime}\left(\mathrm{H}-2^{\prime}\right)$, indicating its $\alpha$-orientation. Thus all of these data confirmed the structure for 2 with an epoxide of $\alpha$-orientation located between $\mathrm{C}-8$, and $\mathrm{C}-8^{\prime}$, named as kadlongirin $\mathrm{B}$.

Compound 3 was obtained as yellow amorphous powder. Its molecular formula, $\mathrm{C}_{15} \mathrm{H}_{20} \mathrm{O}_{2}$, was determined by the pseudo-molecular ion peak $[\mathrm{M}+\mathrm{Na}]^{+}$in the positive HRESI-MS at $\mathrm{m} / z 255.1361$ (Calcd 255.1360), indicating 6 degrees of unsaturation. The IR spectra revealed the presence of hydroxyl group $\left(3423 \mathrm{~cm}^{-1}\right)$ and phenolic group (1449, $\left.1643 \mathrm{~cm}^{-1}\right){ }^{23)}$ The ${ }^{1} \mathrm{H}-\mathrm{NMR}$ spectrum of 1 (Table 1) showed two aromatic protons $\left(\delta_{\mathrm{H}} 6.55, \mathrm{~s} ; 6.73, \mathrm{~s}\right)$, suggesting a tetrasubstituted aromatic spin-system with a para configuration. A series of complex signals at $\delta_{\mathrm{H}} 4.64,4.88(2 \mathrm{H}$, each br s), $\delta_{\mathrm{H}} 3.79(1 \mathrm{H}, \mathrm{ddd}, 2.4,4.8,6.8 \mathrm{~Hz}), \delta_{\mathrm{H}} 3.58(1 \mathrm{H}, \mathrm{dd}, 7.6$, $8.4 \mathrm{~Hz})$, and $2.65(1 \mathrm{H}, \mathrm{m})$ was indicative of a characteristic olefinic methylene and carbinolic and two benzyl hydrogens. Further signals at $\delta_{\mathrm{H}} 1.25(3 \mathrm{H}, \mathrm{d}, 7.1 \mathrm{~Hz}), \delta_{\mathrm{H}} 1.65(3 \mathrm{H}, \mathrm{s})$, and $2.08(3 \mathrm{H}, \mathrm{s})$ revealed the presence of two aliphatic groups and an aromatic methyl group in the molecule. The ${ }^{13} \mathrm{C}$-NMR data (Table 2) and DEPT experiments clearly indicated the basic $\mathrm{C}_{15}$-sesquiterpene skeleton of the cadinane skeleton. ${ }^{24,25)}$ The structure of $\mathbf{3}$ was elucidated from HSQC, ${ }^{1} \mathrm{H}-{ }^{1} \mathrm{H}$ COSY, and HMBC studies (Fig. 4a). The HMBC correlations of $\mathrm{H}_{3}-15$ to $\mathrm{C}-2, \mathrm{C}-3$, and $\mathrm{C}-4$, and $\mathrm{H}-4$ to $\mathrm{C}-2$, con- 
Table 2. ${ }^{1} \mathrm{H}$ - and ${ }^{13} \mathrm{C}-\mathrm{NMR}$ Assignments of $\mathbf{3}$

\begin{tabular}{crl}
\hline \hline & & 3 \\
& & \multicolumn{2}{l}{} \\
\cline { 2 - 3 }$\delta_{\mathrm{C}}$ (mult.) & \multicolumn{1}{c}{$\delta_{\mathrm{H}}$ (mult., $\left.J, \mathrm{~Hz}\right)$} \\
\hline 1 & $115.3 \mathrm{~d}$ & $6.55(\mathrm{~s})$ \\
2 & $154.9 \mathrm{~s}$ & \\
3 & $123.4 \mathrm{~s}$ & $6.73(\mathrm{~s})$ \\
5 & $131.7 \mathrm{~d}$ & $3.58(\mathrm{dd}, 7.6,8.4)$ \\
$6 \alpha$ & $44.7 \mathrm{~d}$ & $1.78(\mathrm{ddd}, 6.8,7.6,12.2)$ \\
$6 \beta$ & $33.1 \mathrm{t}$ & $2.03(\mathrm{ddd}, 2.4,8.4,12.2)$ \\
7 & & $3.79(\mathrm{ddd}, 2.4,4.8,6.8)$ \\
8 & $71.7 \mathrm{~d}$ & $2.65(\mathrm{~m})$ \\
9 & $41.9 \mathrm{~d}$ & \\
10 & $139.8 \mathrm{~s}$ & \\
11 & $128.3 \mathrm{~s}$ & $4.88(\mathrm{~s})$ \\
$12 \mathrm{a}$ & $150.3 \mathrm{~s}$ & $4.64(\mathrm{~s})$ \\
$12 \mathrm{~b}$ & $113.9 \mathrm{t}$ & $1.65(\mathrm{~s})$ \\
13 & & $1.25(\mathrm{~d}, 7.1)$ \\
14 & $19.7 \mathrm{q}$ & $2.08(\mathrm{~s})$ \\
15 & $21.8 \mathrm{q}$ & \\
\hline & $15.9 \mathrm{q}$ &
\end{tabular}

All spectra were recorded in $\mathrm{CD}_{3} \mathrm{OD}$ at $400 \mathrm{MHz} . \delta$ in ppm, $J$ in $\mathrm{Hz}$.

(a)

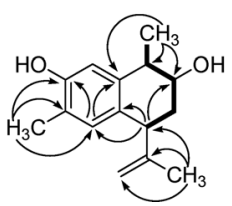

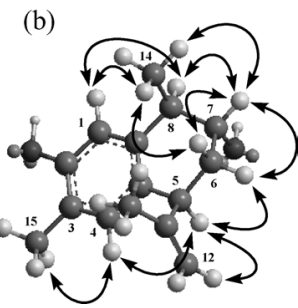

Fig. 4. (a) ${ }^{1} \mathrm{H},{ }^{1} \mathrm{H}$ COSY $(-)$ and Key HMBC $(\mathrm{H} \rightarrow \mathrm{C})$ Correlations of 3; (b) Key ROESY $(\leftrightarrow)$ Correlations of $\mathbf{3}$

Table 3. Anti-HIV-1 Activities of the New Compounds

\begin{tabular}{crlr}
\hline \hline Compound & $\mathrm{CC}_{50}(\mu \mathrm{g} / \mathrm{ml})^{a)}$ & $\mathrm{EC}_{50}(\mu \mathrm{g} / \mathrm{ml})^{b)}$ & $\mathrm{TI}_{\left(\mathrm{CC}_{50} / \mathrm{EC}_{50}\right)^{c)}}$ \\
\hline $\mathbf{1}$ & 96.1 & 51.8 & 1.9 \\
$\mathbf{2}$ & 106.7 & 16.0 & 6.7 \\
$\mathbf{3}$ & 61.5 & 12.8 & 4.8 \\
Positive control AZT & 1146.1 & $2.03 \mathrm{ng} / \mathrm{ml}$ & 564571.4 \\
\hline
\end{tabular}

a) $\mathrm{CC}_{50}=$ concentration causing $50 \%$ cellular cytotoxicity. b) $\mathrm{EC}_{50}=50 \%$ effective concentration. c) $\mathrm{TI}=$ therapeutic index.

firmed the location of the phenolics function was located at C-2. In addition, the following HMBC correlations: $\mathrm{H}_{3}-14$ to C-7, C-8, and C-9; $\mathrm{H}-5$ to $\mathrm{C}-7$, and $\mathrm{C}-10$; and $\mathrm{H}_{3}-13$ to $\mathrm{C}-5$, $\mathrm{C}-11$, and $\mathrm{C}-12$, as well as the ${ }^{1} \mathrm{H}-{ }^{1} \mathrm{H}$ COSY spin system $\mathrm{H}-$ $5 / \mathrm{H}_{2}-6 / \mathrm{H}-7 / \mathrm{H}-8 / \mathrm{H}_{3}-14$, suggested that a hydroxyl group and an isopropenyl group were located at $\mathrm{C}-7$ and $\mathrm{C}-5$, respectively. The linkage of the $p$-menthane moiety with the aromatic moiety was determined through the correlations of $\mathrm{H}_{3}-$ 14 to C-9, and H-5 to C-10. The ROESY spectrum (Fig. 4b) further determined the stereochemistry of 3: correlations of $\mathrm{H}_{3}-14$ with $\mathrm{H}-1, \mathrm{H}-7$, and $\mathrm{H}-6 \beta$, and $\mathrm{H}-7$ with $\mathrm{H}_{2}-6$ and $\mathrm{H}-8$, suggested that $\mathrm{H}_{3}-14$ and $\mathrm{H}-7$ were in $\beta$-orientation; correlations of H-5 with H-4, and H-6 $\alpha$ showed that $\mathrm{H}-5$ should be positioned on the $\alpha$-orientation. Therefore 2,7-dihydroxy11,12-dehydrocalamenene was assigned as showed in Fig. 1.

The anti-HIV activity was indicated as potencies of the new compounds $\mathbf{1}-\mathbf{3}$ in preventing the cytopathic effects of
HIV-1 in C8166 cells, with cytotoxicity measured in parallel with the determination of antiviral activity using AZT as a positive control $\left(\mathrm{EC}_{50}=2.03 \mathrm{ng} / \mathrm{ml}\right.$ and $\mathrm{CC}_{50}=1146.08$ $\mu \mathrm{g} / \mathrm{ml})$. Compound 2 exhibited weak anti-HIV-1 activity with an $\mathrm{EC}_{50}$ value of $16.0 \mu \mathrm{g} / \mathrm{ml}$ and TI value of 6.7 (Table 3).

\section{Experimental}

Optical rotations were measured on a JASCO DIP-370 digital polarimeter. IR spectra were obtained on a Bio-Rad FtS-135 spectrophotometer with $\mathrm{KBr}$ pellets, whereas UV data were obtained using a UV-210A spectrometer. MS were recorded on a VG Auto Spec-3000 spectrometer. 1D-NMR spectra were obtained on a Bruker DRX-400 instrument with TMS as an internal standard, and 2D-NMR spectra were obtained on a Bruker DRX-500 instrument with TMS as an internal standard. Column chromatography (CC) and TLC: Si gel (200-300 mesh) from Qingdao Marine Chemical Factory, Quingdao, People's Republic of China.

Plant Material The leaves and stems of $K$. longipedunculata were collected in Yibin region of Sichuan Province, China, in August 2004, and identified by Prof. Xi-Wen Li, Kunming Institute of Botany. A voucher specimen has been deposited in the Herbarium of the Kunming Institute of Botany, Chinese Academy of Sciences.

Extraction and Isolation The air-dried and powdered leaves and stems $(10 \mathrm{~kg})$ of $\mathrm{K}$. longipedunculata were extracted with $70 \%$ aqueous $\mathrm{Me}_{2} \mathrm{CO}$ $(3 \times 301)$ at room temperature to yield an extract, which was successively extracted with petroleum ether and EtOAc. The EtOAc extract was evaporated to dryness under reduced pressure to give an extract $(400 \mathrm{~g})$ that was separated by $\mathrm{Si}$ gel $\mathrm{CC}(2.0 \mathrm{~kg}, 200-300$ mesh $)$ and eluted with a $\mathrm{CHCl}_{3} / \mathrm{Me}_{2} \mathrm{CO}$ gradient system $(9: 1,8: 2,7: 3,6: 4,5: 5)$ to give fractions $1-5$. Fractions $1(180 \mathrm{~g})$ and $2(108 \mathrm{~g})$ were subjected to $\mathrm{CC}$ with Petroleum ether $/\left(\mathrm{CH}_{3}\right)_{2} \mathrm{CO}$ gradient system $(40: 1,20: 1,10: 1,5: 1,2: 1)$ to afford 5 fractions, which were further purified by semipreparative HPLC (Agilent 1100 HPLC system, U.S.A.; Zorbax SB-C-18, Agilent, $9.4 \mathrm{~mm} \times 25 \mathrm{~cm}$, U.S.A., $\left.\mathrm{MeOH}-\mathrm{H}_{2} \mathrm{O}\right)$ to give compounds $\mathbf{1}(2 \mathrm{mg}), \mathbf{3}(6 \mathrm{mg}), 4(8 \mathrm{mg}), \mathbf{5}$ $(15 \mathrm{mg}), 9(152 \mathrm{mg}), \mathbf{8}(12 \mathrm{mg})$, and $\mathbf{1 0}(14 \mathrm{mg})$. Fraction $3(30 \mathrm{~g})$ was subjected to $\mathrm{CC}$ with $\mathrm{CHCl}_{3} / \mathrm{CH}_{3} \mathrm{OH}(20: 1)$ to afford 6 fractions that were further purified by Sephadex LH-20 $\left(\mathrm{CH}_{3} \mathrm{OH}\right)$ to afford another 8 fractions, which were purified by semipreparative $\mathrm{HPLC}\left(\mathrm{MeOH}-\mathrm{H}_{2} \mathrm{O}\right)$ to give compounds $2(8 \mathrm{mg}), \mathbf{6}(16 \mathrm{mg})$, and $7(71 \mathrm{mg})$.

Kadlongirin A (1): Yellowish oil; $[\alpha]_{\mathrm{D}}^{27.8}+46(c=0.73, \mathrm{MeOH})$; UV $(\mathrm{MeOH}) \lambda_{\max }(\log \varepsilon): 206$ (5.07), 276 (3.77), 314 (2.87), 360 (2.91) nm; IR (KBr) $v_{\max }: 3426,2994,2961,2936,2834,1593,1512,1463,1423,1410$, $1372,1329,1267,1235,1163,1126,1099,1082,1026,1009,985,935$, $870,810,764 \mathrm{~cm}^{-1}$; ${ }^{1} \mathrm{H}-(400 \mathrm{MHz})$ and ${ }^{13} \mathrm{C}-\mathrm{NMR}(100 \mathrm{MHz})$ : see Table 1; positive ESI-MS: $m / z 935[2 \mathrm{M}+\mathrm{K}]^{+}$(3), $919[2 \mathrm{M}+\mathrm{Na}]^{+}(44), 487$ $[\mathrm{M}+\mathrm{K}]^{+}(21), 471[\mathrm{M}+\mathrm{Na}]^{+}(45), 417(100), 399(4), 317(8), 209$ (31); positive HR-ESI-MS: $m / z 471.1996[\mathrm{M}+\mathrm{Na}]^{+}$, (Calcd for $\mathrm{C}_{24} \mathrm{H}_{32} \mathrm{O}_{8} \mathrm{Na}$, 471.1994).

Kadlongirin B (2): Yellowish oil; $[\alpha]_{\mathrm{D}}^{27.5}+85(c=0.50, \mathrm{MeOH})$; UV $(\mathrm{MeOH}) \lambda_{\max }(\log \varepsilon): 206$ (5.16), 275 (3.93), 363 (2.94), 374 (2.80) nm; IR (KBr) $v_{\text {max }}: 3440,2937,2838,1630,1513,1463,1425,1330,1263,1229$, 1126, $1102 \mathrm{~cm}^{-1}$; ${ }^{1} \mathrm{H}-(400 \mathrm{MHz})$ and ${ }^{13} \mathrm{C}-\mathrm{NMR}(100 \mathrm{MHz})$ : see Table 1; positive ESI-MS: $m / z 915[2 \mathrm{M}+\mathrm{Na}]^{+}(70), 485[\mathrm{M}+\mathrm{K}]^{+}(7), 469[\mathrm{M}+\mathrm{Na}]^{+}$ (100), 441 (65); positive HR-ESI-MS: $m / z 469.1850[\mathrm{M}+\mathrm{Na}]^{+}$, (Calcd for $\left.\mathrm{C}_{24} \mathrm{H}_{30} \mathrm{O}_{8} \mathrm{Na}, 469.1838\right)$.

2,7-Dihydroxy-11,12-dehydrocalamenene (3): Yellow amorphous powder; $[\alpha]_{\mathrm{D}}^{21.5}-85(c=0.59, \mathrm{MeOH}) ; \mathrm{UV}(\mathrm{MeOH}) \lambda_{\max }(\log \varepsilon): 205(4.80), 282$ (3.65), 334 (2.37), 354 (2.32), $365(2.44) \mathrm{nm}$; IR (KBr) $v_{\max }: 3423,2964$, 2931, 2875, 1643, 1621, 1504, 1449, 1413, 1373, 1260, 1189, 1131, 1052, $1031,1005,893 \mathrm{~cm}^{-1}$; ${ }^{1} \mathrm{H}-(400 \mathrm{MHz})$ and ${ }^{13} \mathrm{C}-\mathrm{NMR}(100 \mathrm{MHz})$ : see Table 2; positive ESI-MS: $m / z 487[2 \mathrm{M}+\mathrm{Na}]^{+}(52), 255[\mathrm{M}+\mathrm{Na}]^{+}(51), 252$ (100), 173 (16); positive HR-ESI-MS: $m / z 255.1361[\mathrm{M}+\mathrm{Na}]^{+}$, (Calcd for $\left.\mathrm{C}_{15} \mathrm{H}_{20} \mathrm{O}_{2} \mathrm{Na}, 255.1360\right)$.

Anti-HIV-1 Assay The cytotoxicity assay against C8166 cells $\left(\mathrm{CC}_{50}\right)$ was assessed using the MTT method, and anti-HIV-1 activity was evaluated by the inhibition assay for the cytopathic effects of HIV-1 $\left(\mathrm{EC}_{50}\right){ }^{26)}$

Acknowledgements We gratefully acknowledge the support of the Natural Science Foundation of Yunnan Province (2005XY04 and 2006B0042Q), the Western Doctoral Foundation of Chinese Academy of Sciences (presided by J.-X. Pu), and the key Scientific and Technological projects of Yunnan province (2004NG12, 2005B0048M). 


\section{References}

1) “Compilation of Chinese Herb Medicine," Vol. 1, ed. by People's Publishing House, Beijing, 1975, p. 581.

2) "Pharmacopoeia of the People's Republic of China," Vol. 1, 1977, pp. 396-397.

3) Liu J. S., Huang M. F., Phytochemistry, 31, 957-960 (1992).

4) Tan R., Li L. N., Fang Q. C., Planta Med., 50, 414 417 (1984).

5) Li L. N., Xue H., Li X., Planta Med., 57, 169-171 (1991).

6) Liu J. S., Pan Y. P., Acta Chim. Sin., 49, 308-312 (1991).

7) Sun Q. Z., Chen D. F., Ding P. L., Ma C. M., Kakuda H., Nakamura N., Hattori M., Chem. Pharm. Bull., 54, 129-132 (2006).

8) Li L. N., Xue H., Kangouri K., Ikeda A., Omura S., Planta Med., 55, 294-296 (1989).

9) Tan R., Xue H., Li L. N., Planta Med., 57, 87-88 (1991).

10) Liu J. S., Huang M. F., Acta Chim. Sin., 49, 502-506 (1991).

11) Pu J. X., Xiao W. L., Lu Y., Li R. T., Li H. M., Zhang L., Huang S. X., Li X., Zhao Q. S., Zheng Q. T., Sun H. D., Org. Lett., 22, 5079-5082 (2005).

12) Pu J. X., Li R. T., Xiao W. L., Gong N. B., Huang S. X., Lu Y., Zheng Q. T., Lou L. G., Sun H. D., Tetrahedron, 62, 6073-6081(2006).

13) Pu J. X., Huang S. X., Ren J., Xiao W. L., Li L. M., Li R. T., Li L. B., Liao T. G., Lou L. G., Zhu H. J., Sun H. D., J. Nat. Prod., 70, 17061711 (2007).

14) Holloway D., Scheinmann F., Phytochemistry, 13, 1233-1236 (1974).
15) Hattori M., Hada S., Kawata Y., Tezuka Y., Kikuchi T., Namba T., Chem. Pharm. Bull., 35, 3315-3322 (1987).

16) Tan R. X., Jakupovic J., Jia Z. J., Planta Med., 56, 475-477 (1990).

17) Li H. R., Feng Y. L., Yang Z. G., Wang J., Daikonya A., Kitanaka S., Xu L. Z., Yang S. L., Chem. Pharm. Bull., 54, 1022-1025 (2006).

18) Braz Fo R., De Carvalho M. G., Gottlieb O. R., Planta Med., 50, 5355 (1984).

19) Luo G., Liu J. S., Acta Chim. Sin., 50, 515-520 (1992).

20) Gnabre J. N., Ito Y., Ma Y., Huang R. C., J. Chromatogr., 719, 353364 (1996)

21) Martins R. C. C., Latorre L. R., Sartorelli P., Kato M. J., Phytochemistry, 22, 843-846 (2000).

22) Filho A. A. daS., Albuquerque S., Silva M. L. A. e., Eberlin M. N., Tomazela D. M., Bastos J. K., J. Nat. Prod., 67, 42-45 (2004).

23) Siva G. H., Teles H. L., Zanardi L. M., Young M. C. M., Eberlin M. N., Hadad R., Pfenning L. H., Costa-Neto C. M., Castro-Gamboa I., Bolzani V. daS., Araújo Â. R., Phytochemistry, 67, 1964-1969 (2006).

24) Zhang H. L., Nagatsu A., Okuyama H., Mizukami H., Sakakibara J., Phytochemistry, 48, 665-668 (1998).

25) Nagashima F., Momosaki S., Watanabe Y., Takaoka S., Huneck S., Asakawa Y., Phytochemistry, 42, 1361-1366 (1996).

26) Wang J. H., Tam S. C., Huang H., Ouyang D. Y., Wang Y. Y., Zheng Y T., Biochem. Biophys. Res. Commun., 317, 965-971 (2004). 